\title{
TOWARD BUILDING ENERGY REDUCTION THROUGH SOLAR ENERGY SYSTEMS RETROFIT OPTIONS: AN EQUEST MODEL
}

\author{
M. Javad Dehghani a, P. McManamon a, A. Ataei ${ }^{a}$ * \\ ${ }^{\text {a }}$ University of Dayton, Department of Electro-Optics and Photonics, 300 College Park Dr, Dayton, Ohio, USA, \\ e-mail: ataeia1@udayton.edu
}

Received: 10.01.2018 / Accepted: 24.02.2018 / Revised: 30.03.2018 / Available online: 31.05.2018

DOI: 10.2478/jaes-2018-0007

KEY WORDS: Retrofitting measures, Building Energy Modeling, Photovoltaic, Daylighting Control System, Trombe wall.

\begin{abstract}
:
Office buildings are responsible for a great portion of total energy consumption. In this study, solar system based retrofitting measures such as daylighting control system (DCS), Trombe wall (TW) and photovoltaic (PV) systems are modeled to an office building located in Dayton, Ohio, United States. An energy modeling tool, eQuest is utilized to analyze the economic and environmental impacts of the proposed single retrofitting measures along with the combined measure to identify the optimized building energy reduction opportunity. Compared to the baseline energy consumption, adopting single energy efficiency measures such as PV, DCS, TW, and overhangs/fins to windows results in about $25,10,9,1$ percentages of energy reduction respectively. In terms of economic perspectives, overhang and fins provide the best simply payback time around 1 year. Other solar system based retrofitting measures such as TW, DCS and PV can provide economic simple payback with 1.5, 2.5, and 12 years respectively. PV turned out to be the most costly options although it provides the largest energy savings which lead to the largest CO2 reductions. Adopting the combined system along with $50 \mathrm{~kW}$ photovoltaic array to the rooftop results in 45 percent office building energy reduction.
\end{abstract}

\section{INTRODUCTION}

Almost half of the total energy used in the United States is utilized in operating buildings (EIA, 2018). There are about 5 billion of commercial buildings in the United States, and 17 percent of total floor-space are occupied by office buildings (EIA, 2012). In addition, thirty three percent of the total worldwide greenhouse-gas emission is generated from buildings (Wan et al., 2011). Furthermore, much concern has been raised about global warming and its impacts on the environment in recent years (Ataei and Dehghani, 2017).Therefore, adopting energy efficiency measures has become more important aspect of designing a building (Ke et al., 2013). Recent global trends emphasize implementing energy policies to improve energy efficiency and decrease total energy consumption to attain lowcarbon energy-savings. U.S. Department of Energy is targeting 2025 to market net-zero energy commercial buildings (Hedrick and Porter, 2011).

Various level of numerical simulation tools are considered to improve building energy efficiency and assess the feasibility of the application of solar systems such as photovoltaic and solar passive systems (EVO, 2010). Diverse array of building energy simulation tools such as such as EnergyPlus (https://energyplus.net/) and eQUEST (http://www.doe2.com/equest/). Bojic et al. (2014) simulated a house by EnergyPlus, TRACE (http://www.trane.com/trace)
(Ataei and Dehghani, 2016) and ECOTECT (http://usa.autodesk.com/ecotect-analysis/) have been developed and used for improving the energy efficiency of buildings.

These tools are complicated and takes considerable time to comprehend (Kim et al., 2011). Zhu (2006) applied the eQuest to simulate the effect of adopting energy efficacy measures on building. The study determined the optimized solution to achieve the Energy Star designation to facilitate the decision making process of the facility managers. Passive solar techniques are claimed to be able to reduce the annual heating demand up to 25 percent (Liu and Feng, 2012). However, often time, much of the passive solar designs are done without any scientifically rigorous analysis or simulations. Application of the passive solar systems are sometimes practiced by intuition, imitation, or rules-of-thumb (Balcomb, 1992) however, a study showed that well-designed Trombe walls can enhance interior comfort (Jie et al., 2007).

Trombe wall, an energy-efficient passive solar system (Sun et al., 2011) and passive solar measures and strategies such as daylighting control system and façade options have been modeled by experimental-numerical methods (Koyunbaba et al., 2013). Ellis (2003) developed and validated the effectiveness of the Trombe wall in several cells model with the EnergyPlus. Sami and Gassman (2006) combined three analytical methods

\footnotetext{
* Corresponding author: Dr. Abtin Ataei, e-mail: ataeia1@udayton.edu
} 
for Trombe walls thermal performance simulations: eQuest to analyze energy of hourly 'lumped node' in a whole building, RadTherm for thermal analysis, and nPhase, a computational fluid dynamics (CFD) model. Yuet et al. (2008) applied eQuest to study the effect of numerous parameters for improving the building energy efficiency. The study showed that airconditioner's energy consumption can be saved by shielding the building envelope and insulating external wall at the rate of 11.3 percent and 11.6 percent, respectively. Jaber and Ajib (2011) used TRNSYS program for simulation and analysis of thermal behavior, environment and economic effects of Trombe wall in a residential building in Mediterranean climate. The simulation illustrated that optimum function of economic and thermal parameters of Trombe wall area ratio is $37 \%$. Stazi et al. (2011) investigated thermal performance of solar walls in a residential building by EnergyPlus simulation. The results showed that the solar wall has capability of heating energy conversation in winter and has optimum representation by utilization of double glazing. Solar wall increases cooling energy demand in the summer and therefore, heating load reduces by adopting shading and ventilation on the solar wall. Koyunbaba and Yilmaz (2012) by a model test room built, compered the energy performance of single glass, double glass and a-Si semi-transparent PV module integrated on the Trombe wall façade. They applied the Computational fluid dynamics (CFD) for simulation of the model and experimental results for comparison. The model demonstrated that simulated and experimental outcomes have a good agreement, as well as ability of a CFD simulation for prediction of heat transfer rates. Albanese et al. (2012) evaluated a heat pipe passive solar wall by computer model and experimental alterations as follows: fluid fill levels, insulation on the adiabatic section, and fins on the outside of the condenser section. The results indicated good agreement between experimental and simulated data. Martinez et al. (2012) modeled the energy consumption performance of a 1970s office building by applying two energy simulation software tools and calibrating data using original utility, electricity, and gas bills, and the regional weather data, using passive strategies to the building façade, a few options were recommended after the calibration of the models. Irshad et al. (2014) applied TRNSYS software to integrate the combined impacts of climate conditions, building construction details, material thermal properties, photovoltaic and Trombe wall (PVTW) details, and building orientation. It simulated energy consumption of single zone building integrated with PV-TW to calculate potential cost savings, energy consumption and emission reduction compared to the baseline scenario. Sozer (2010) argued that energy consumption of older hotels were significantly high due to unestablished regulations and limits. The study utilized eQuest to illustrate the effectiveness of the passive building design. The results showed that the energy consumption for heating and cooling of older hotels could be reduced about forty percent by adopting multiple energy efficiency measures. Gould and Hawkins (2015) analyzed two multifamily buildings with two years of accumulated data achieved from the utility bill. Each building is followed the EPA-modified ANSI/ASHRAE/IES Standard 90.1-2004 but the buildings have minor differences in geometry and mechanical systems. The study paid attention specifically to the impacts of weather, daylighting and ventilation, and they predicted actual energy consumption. Ataie and Dehghani (2017) investigated the energy conservation in a multifamily building located in Dayton, Ohio by integration of an ammonia ground source heat pump (R-717 GSHP) instead of a typical heat pump and a
Trombe wall. The utilization of those measures decreased $20 \%$ and $9 \%$ of energy consumption in the building, respectively.

In this paper, we present a model which predict the efficiency and the effectiveness of overhang/fins, daylighting control system (DCS), Trombe wall (TW) and photovoltaic (PV) in an office building located in Dayton Ohio, United States. The eQuest model was used to assess and optimize the proposed retrofitting measures and to estimate the potential monthly energy saving achieve by each single measure and the combined effect respectively.

\section{BASELINE MODEL DEVELOPMENT}

A four-story office building over the parking garage in Dayton, Ohio is selected for this study. The building is oriented zero degree, area of each floor is $729 \mathrm{~m} 2$ and the floor to floor height is $4 \mathrm{~m}$. The vertical fenestration area of each envelope side is equal to 40 percent of the gross wall area. The exterior windows feature $6 \mathrm{~mm}$ double clear glass and $13 \mathrm{~mm}$ air gap in a broken fixed Aluminium frame. Baseline model does not have any overhangs or fins but some will be added in the adopting measures part in the next section. The exterior doors, designated on three sides of the first floor, feature double layers with the UValue of $4.65 \mathrm{~W} / \mathrm{m} 2 . \mathrm{K}$. Table 1 shows the properties of the interior and exterior walls.

Table 1. Properties of the building exterior and interior walls

\begin{tabular}{|c|c|c|}
\hline Wall type & $\begin{array}{c}\mathrm{U}-\text { Value } \\
\left(\mathrm{W} / \mathrm{m}^{2} . \mathrm{K}\right)\end{array}$ & $\begin{array}{c}\text { Thickness } \\
(\mathrm{mm})\end{array}$ \\
\hline Exterior Wall & 0.22 & 300 \\
\hline Roof & 0.37 & 250 \\
\hline Ground Floor & 0.27 & 250 \\
\hline Interior Wall & 2.38 & 25 \\
\hline Ceiling & 2.92 & 12 \\
\hline Internal Floor & 5.19 & 127 \\
\hline
\end{tabular}

The floor occupancy equals to 45 people, operating a Monday to Friday schedule between 8:00 AM to 5:00 PM. The cooling source of the building includes a $320 \mathrm{~kW}$ hermetic reciprocating air cooled chiller and the heating source is composed of a 146 $\mathrm{kW}$ natural gas-fired boiler which utilize a water loop system to transfer the cooled and hot water respectively in summer and winter months to the coils of a standard variable air volume (VAV) system for four thermal zones located in each story where the air is recalculated by the return duct.

Domestic hot water with 30 percent return is supplied by the boiler too. The baseline building model in the eQuest is depicted in Figure 1. 


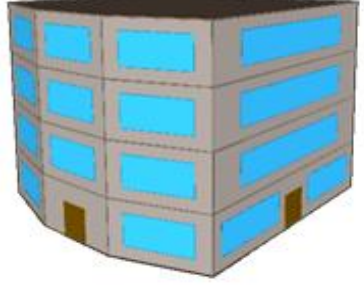

(a)

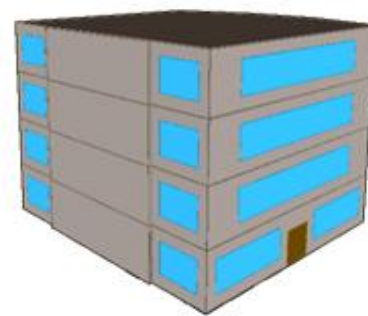

(b)
Figure 1. The baseline model of the building considered for the case study (a north-west view, b south-east view)

The annual electricity and gas demands in the office building were provided from actual utility bills as well as calculated in the eQuest. Table 2 compares the results achieved from the bills to those from the eQuest after performing the geometric, internal loads and HVAC (heating ventilation air-conditioning) system simulation.

As can be seen in the table 2, there are less than 3 percent differences in total building energy demand estimation between the eQuest output and the actual amount.

Table 2. The office building annual energy demand given from the bills and from the eQuest

\begin{tabular}{|c|c|c|c|}
\hline Demand & $\begin{array}{c}\text { Given from } \\
\text { the energy } \\
\text { bills } \\
(\mathrm{MWh})\end{array}$ & $\begin{array}{c}\text { Calculated in } \\
\text { eQuest } \\
\text { (MWh) }\end{array}$ & $\begin{array}{c}\text { Difference } \\
(\%)\end{array}$ \\
\hline Electricity & 259 & 253.64 & 2 \\
\hline Gas & 141 & 134.78 & 4.4 \\
\hline Total energy & 400 & 388.42 & 2.9 \\
\hline
\end{tabular}

The monthly electricity and gas consumptions of the baseline model calculated by the eQuest, are shown in Figure 2. These twelve months data illustrate a typical seasonal trend of electricity consumption for space cooling during the summer months and the very strong seasonal trend of natural gas consumption for space heating during the winter months.

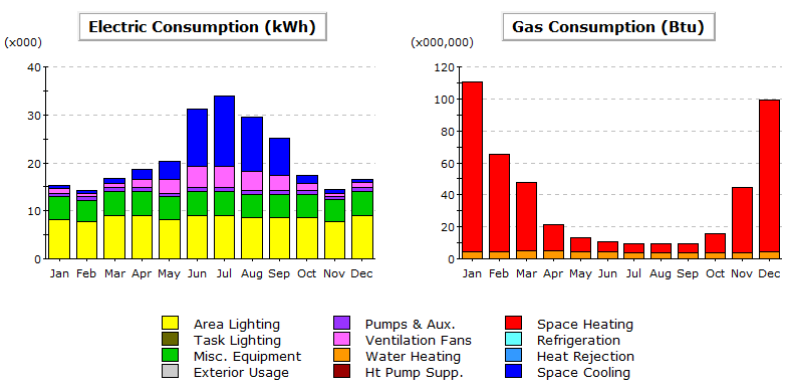

Figure 2. Monthly baseline model energy consumption

\section{APPLICATION OF RETROFITTING MEASURES}

In this section, four different retrofitting measures are adopted and the impacts of each retrofit on the building energy consumption performances are evaluated with the eQuest. Then, the effect of all combined measures are evaluated and calibrated to achieve the optimum energy saving.

\subsection{Overhangs and fins}

Overhangs and fins are devices for reducing the total space cooling load in summer. The projections of these measures were calibrated between $30 \mathrm{~cm}$ to $90 \mathrm{~cm}$. The modeling results showed that the best energy saving occurred at the depth of 90 $\mathrm{cm}$. The model showed that the northern side does not need any overhangs or fins. Furthermore the model suggests that, for better operation of Trombe walls (TW), the fenestrations of the southern side needed only overhangs. Table 3 shows the best geometry of the fins and overhangs for the fenestrations in the office building.

Table 3. The selected geometry of overhangs and fins

\begin{tabular}{|c|c|c|}
\hline \multirow{2}{*}{$\begin{array}{c}\text { Façade } \\
\text { windows }\end{array}$} & Overhang & Fin \\
\cline { 2 - 3 } & Projection $(\mathrm{cm})$ & Projection $(\mathrm{cm})$ \\
\hline North & -- & -- \\
\hline South & 90 & -- \\
\hline East & 90 & 90 \\
\hline West & 90 & 90 \\
\hline
\end{tabular}

Table 4 shows the overall estimated energy and economic analysis of the building after adopting overhangs and fins by using the eQuest. Compared to the baseline model, energy consumption decreased by 1.3 percent. Although the amount of reduction is not significant, it is noticeable by applying very simple energy efficiency measures with very quick simple payback time around 1 year.

The monthly electricity and gas consumptions after adopting the overhangs and fins calculated by eQuest are given in Figure 3.

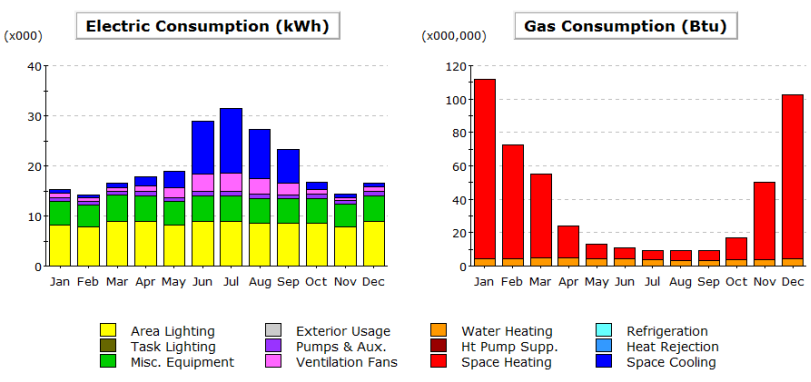

Figure 3. Monthly energy consumption after adopting the overhangs and fins

\subsection{Daylighting Control System}

Lamps lighting for the primary sidelighted area should have more than one separate multilevel photo controllers for an enclosed space that equals or exceeds $23 \mathrm{~m} 2$ in the combined primary sidelighted area. After calibrating the method and positioning the sensors in the eQuest model, the results showed that the automatic daylighting controls for primary sideliglted areas may conserve 10.2 percent of the overall energy consumption. Table 5 shows the characteristics of the control systems. 
Skylight is one method of daylighting control systems but the eQuest results showed that by fitting this system into the roof, the overall energy consumption is increased. Thus, skylight measure was eliminated from the model. Table 6 shows the overall energy and economic analysis of the model after adopting the daylighting control system. Although the total capital investment for installing daylight control system is high, it provides significant energy and cost savings for the electricity bills which leads to relatively quick simple payback time of 2.5 years. The monthly electricity and gas consumptions after adopting thedaylighting control system calculated by eQuest are given in Figure 4.

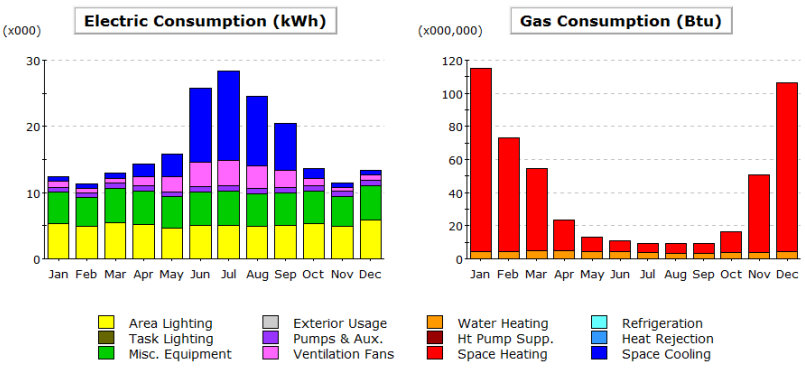

Figure 4. Monthly energy consumption after adopting the daylighting control system

Table 4. Annual energy consumption, energy saving, CO2 emission reduction and economic analysis after adopting the overhangs and fins

\begin{tabular}{|c|c|c|c|c|c|c|}
\hline & $\begin{array}{c}\text { Energy Demand } \\
(\mathrm{MWh} / \mathrm{yr})\end{array}$ & $\begin{array}{c}\text { Energy Saving } \\
(\mathrm{MWh} / \mathrm{yr})\end{array}$ & $\begin{array}{c}\mathrm{CO}_{2} \text { reduction } \\
(\mathrm{g} / \mathrm{yr})\end{array}$ & Cost Saving (\$/yr) & $\begin{array}{c}\text { Total capital cost } \\
(\$)\end{array}$ & $\begin{array}{l}\text { Simple payback } \\
\text { time (year) }\end{array}$ \\
\hline Electricity & 241.19 & 12.45 & 6,225 & 1,245 & & \\
\hline Gas & 142.05 & -7.27 & $-3,635$ & -248 & & \\
\hline Total & 383.24 & 5.18 & 2,590 & 997 & 1,097 & 1.1 \\
\hline
\end{tabular}

Table 5. Characteristics of the control systems

\begin{tabular}{|c|c|c|}
\hline Parameters & System 1 & System 2 \\
\hline Control System Operation Mode & Continuous & Continuous \\
\hline Light Set Point & $50(\mathrm{fc})$ & $50(\mathrm{fc})$ \\
\hline Glare View Azimuth & 270 & 270 \\
\hline Control Reference Position & $(24.4,24.4,0.6)$ & 0.3 \\
\hline Minimum Light Fraction & 0.3 & 0.3 \\
\hline Minimum Power Fraction & 0.3 & $(24.4,2.7,7.6)$ \\
\hline
\end{tabular}

Table 6. Annual energy consumption, energy saving, $\mathrm{CO} 2$ emission reduction and economic analysis after adopting the daylighting control system

\begin{tabular}{|c|c|c|c|c|c|c|}
\hline & $\begin{array}{c}\text { Energy } \\
\text { Demand } \\
(\mathrm{MWh} / \mathrm{yr})\end{array}$ & $\begin{array}{c}\text { Energy Saving } \\
(\mathrm{MWh} / \mathrm{yr})\end{array}$ & $\begin{array}{c}\mathrm{CO} 2 \text { reduction } \\
(\mathrm{g} / \mathrm{yr})\end{array}$ & $\begin{array}{c}\text { Cost saving } \\
(\$ / \mathrm{yr})\end{array}$ & $\begin{array}{c}\text { Total capital } \\
\text { cost }(\$)\end{array}$ & $\begin{array}{c}\text { Simple payback } \\
\text { time (year) }\end{array}$ \\
\hline Electricity & 204.55 & 49.09 & 24,545 & 4,909 & & \\
\hline Gas & 144.25 & -9.47 & $-4,735$ & -323 & & \\
\hline Total & 348.8 & 39.62 & 19,810 & 4,586 & 11,465 & 2.5 \\
\hline
\end{tabular}

\subsection{Trombe Wall (TW)}

Trombe Wall is considered as an effective method to save building energy which adopt a passive solar façade system. Trombe wall usually consist of a thermal wall with a clear outer glazing, and a convective air gap in between (Jie et al., 2007). Figure 5 shows Trombe walls installed on the south façade of the model.
In the air gap of the unvented Trombe wall, convection occurs entirely by natural convection. Solar radiation transmitted through the glazing heats the wall surface while the glazing remains cooled by the outdoor environment. The difference in temperature establishes complex convection patterns inside the air gap (Ellis, 2003). 


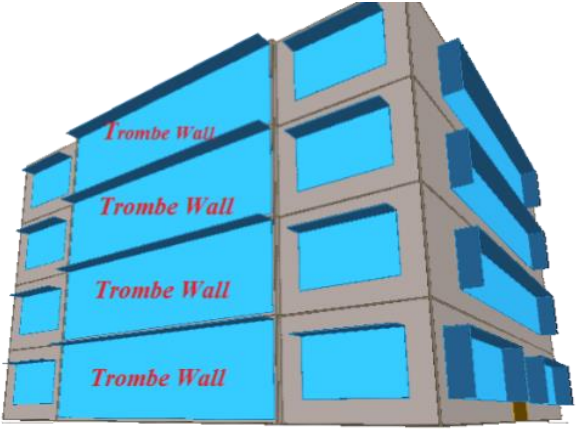

Figure 5. Trombe wall installed on the south façade of the model

Heat transfer coefficients directly related the Nusselt numbers. For most vertical cavities Trombe walls, a correlation based on Wright (1996) and Eqs, (1) (6) are used (Wright, 1996).

$$
\begin{aligned}
& \mathrm{Nu}_{1}=0.0673838 \mathrm{Ra}^{1 / \mathrm{a} a} \\
& 5 \times 10^{4}<R a<10^{6} \\
& \mathrm{Nu}_{1}=0.028154 \mathrm{Ra}^{0.4134} \\
& 10^{4}<\mathrm{Ra}<5 \times 10^{4} \\
& \mathrm{Nu}_{1}=1+1.7596678 \times 10^{-10} \mathrm{Ra}^{2.2984755} \\
& R a \leq 10^{4} \\
& N u_{2}=0.242\left(\frac{R a}{a}\right)^{0.272} \\
& N u=\operatorname{Max}\left(\mathrm{Nu} u_{1}, N u_{2}\right)
\end{aligned}
$$

Then, the net convection coefficient is calculated with Equation (6).

$$
h_{\text {cnet }}=\frac{K N u}{L}
$$

Finally, the total heat flux across the cavity is calculated with Equation (7).

$$
q^{n}=h_{\text {Cnet }}\left(T_{1}-T_{2}\right)
$$

In this study, the unvented Trombe walls are integrated into the 50 percent of the south side gross area because rest of the gross area are designated as the sidelighted area. Using the eQuest model, the optimum characteristics of the unvented Trombe walls can be explored. Table 7 listed the optimum properties of the Trombe wall as a passive heating system for the office building considered.

Table 7. Optimum parameters of the unvented Trombe wall calculated by the eQuest

\begin{tabular}{|c|c|}
\hline Parameters & Values (Unit) \\
\hline Wall height & $4(\mathrm{~m})$ \\
\hline Wall width & $15(\mathrm{~m})$ \\
\hline Outside emissivity & 0.1 \\
\hline Channels width & $15(\mathrm{~cm})$ \\
\hline Exterior surface absorbance & 0.97 \\
\hline Thickness & $30(\mathrm{~cm})$ \\
\hline U-Value & $2.84\left(\mathrm{~W} / \mathrm{m}^{2} . \mathrm{K}\right)$ \\
\hline Glass type & Quadruple Low-E \\
\hline
\end{tabular}

After calibration and optimization of the Trombe wall using the eQuest, the model showed that the Trombe wall may conserve 9.3 percent of the overall energy consumption of the building. Table 8 shows the annual energy consumption, energy saving and economic analysis of the model after adopting the Trombe wall. As can be seen, significant amount of gas consumption are reduced during the winter season because the Trombe wall absorb heat during sunlit hours of winter then slowly release the heat over night. It also suggests that Trombe wall has a great economic feasibility with the 1.5 years of simple payback time.

Table 8. Annual energy consumption, energy saving, $\mathrm{CO} 2$ emission reduction and economic analysis after adopting the Trombe walls

\begin{tabular}{|c|c|c|c|c|c|c|}
\hline & $\begin{array}{c}\text { Energy } \\
\text { Demand } \\
(\mathrm{MWh} / \mathrm{yr})\end{array}$ & $\begin{array}{c}\text { Energy Saving } \\
(\mathrm{MWh} / \mathrm{yr})\end{array}$ & $\begin{array}{c}\mathrm{CO}_{2} \text { reduction } \\
(\mathrm{g} / \mathrm{yr})\end{array}$ & $\begin{array}{c}\text { Cost saving } \\
(\$ / \mathrm{yr})\end{array}$ & $\begin{array}{c}\text { Total capital } \\
\text { cost }(\$)\end{array}$ & $\begin{array}{c}\text { Simple payback time } \\
(\text { year })\end{array}$ \\
\hline Electricity & 255.43 & -1.79 & -895 & -179 & & \\
\hline Gas & 97.03 & 37.75 & 18,875 & 1,288 & & \\
\hline Total & 352.46 & 35.96 & 17,980 & 1,109 & 1,664 & 1.5 \\
\hline
\end{tabular}

The monthly electricity and gas consumptions after applying the retrofitting measure calculated by eQuest are shown in Figure 6. 


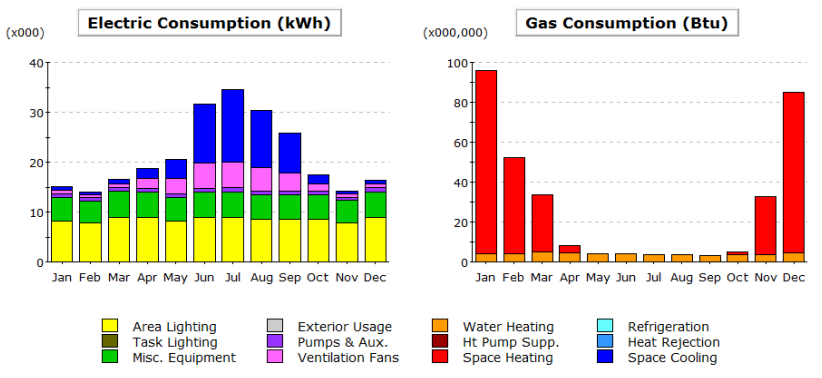

Figure 6. Monthly energy consumption after adopting the Trombe wall

\subsection{Photovoltaic (PV)}

A photovoltaic array with two inverters on 58 percent $(425 \mathrm{~m} 2)$ of the building roof area $(729 \mathrm{~m} 2)$ can generate about 77,162 $\mathrm{kWh}$ electric powers, according to the results of eQuest. The selected array of PV consists of 2 series and 91 parallel modules. Each PV module has following specification; multicrystalline silicon, 11.8 percent efficiency, $285.3 \mathrm{~kW}, 2.42 \mathrm{~m} 2$ per module, with $39.9^{\circ}$ tilt angle. The eQuest model was used to estimate the monthly power generated by the aforementioned PV system and the results are given in Figure 7.

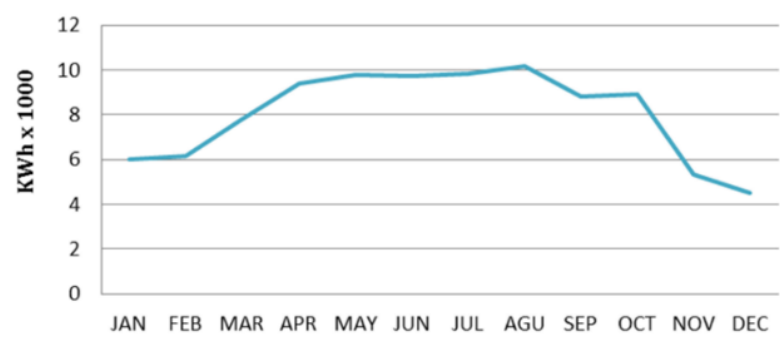

Figure 7. The monthly PV power generation calculated by eQuest

Table 9 shows the annual energy consumption, energy saving and economic analysis of the model after adopting the PV. As can be seen, PV system provides huge energy and cost savings compare to the baseline building energy consumption. However, because of very high total capital investment for PV, the simply payback time is not very appealing.

Table 9. Annual energy consumption, energy saving, $\mathrm{CO} 2$ emission reduction and economic analysis after adopting PV system

\begin{tabular}{|c|c|c|c|c|c|c|}
\hline & $\begin{array}{c}\text { Energy } \\
\text { Demand } \\
(\mathrm{MWh} / \mathrm{yr})\end{array}$ & $\begin{array}{c}\text { Energy Saving } \\
(\mathrm{MWh} / \mathrm{yr})\end{array}$ & $\begin{array}{c}\mathrm{CO}_{2} \text { reduction } \\
(\mathrm{g} / \mathrm{yr})\end{array}$ & $\begin{array}{c}\text { Cost saving } \\
(\$ / \mathrm{yr})\end{array}$ & $\begin{array}{c}\text { Total capital } \\
\text { cost }(\$)\end{array}$ & $\begin{array}{c}\text { Simple payback time } \\
(\text { year })\end{array}$ \\
\hline Electricity & 157.19 & 96.45 & 48,225 & 9,645 & & \\
\hline Gas & 134.78 & 0 & 0 & 0 & & 120,000 \\
\hline Total & 291.97 & 96.45 & 48,225 & 9,645 & 12.4 \\
\hline
\end{tabular}

\subsection{Combined options}

All of the discussed measures (overhangs and fins, daylighting control system, Trombe wall and PV) are considered together and are inputted into the eQuest model for the best operation and maximum energy saving. Figure 8 shows the calibrated model in the eQuest after all combined energy efficiency measures are implemented.
Table 10 shows the total energy consumption after optimizing the combined measures with eQuest. The results indicate that the total energy consumption had decreased 45 percent compared to the baseline model. Combined system could have simple payback around 8 years.

Table 10. Annual energy consumption, energy saving, $\mathrm{CO} 2$ emission reduction and economic analysis after calibrating the all retrofitting measures

\begin{tabular}{|c|c|c|c|c|c|c|}
\hline & $\begin{array}{c}\text { Energy } \\
\text { Demand } \\
(\mathrm{MWh} / \mathrm{yr})\end{array}$ & $\begin{array}{c}\text { Energy } \\
\text { Saving } \\
(\mathrm{MWh} / \mathrm{yr})\end{array}$ & $\begin{array}{c}\mathrm{CO}_{2} \text { reduction } \\
(\mathrm{g} / \mathrm{yr})\end{array}$ & $\begin{array}{c}\text { Cost saving } \\
(\$ / \mathrm{yr})\end{array}$ & $\begin{array}{c}\text { Total capital } \\
\text { cost }(\$)\end{array}$ & $\begin{array}{c}\text { Simple payback } \\
\text { time (year) }\end{array}$ \\
\hline Electricity & 96.15 & 157.49 & 78,745 & 15,749 & & \\
\hline Gas & 119.09 & 15.69 & 7,845 & 535 & & 8.2 \\
\hline Total & 215.24 & 173.18 & 86,590 & 16,284 & 134,226 & \\
\hline
\end{tabular}




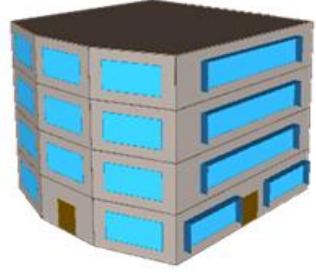

(a)

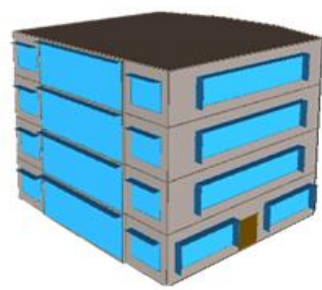

(b)
Figure 8. Calibrated model after combining the proposed options. Overhangs and fins on the west and east sides and the overhangs and Trombe walls on south side: (a north-west view, b south-east view)

Figure 9 shows the comparison of the office building energy consumption for all the retrofit options presented in the study. Compared to the baseline energy consumption, adopting single energy efficiency measures such as PV, DCS, TW, and overhangs/fins to windows results in about $25,10,9,1$ percent of total energy reduction respectively. In addition, adopting all combined retrofitting options along with $50 \mathrm{~kW}$ photovoltaic array to the rooftop results in 45 percent office building energy reduction compared to the baseline scenario.

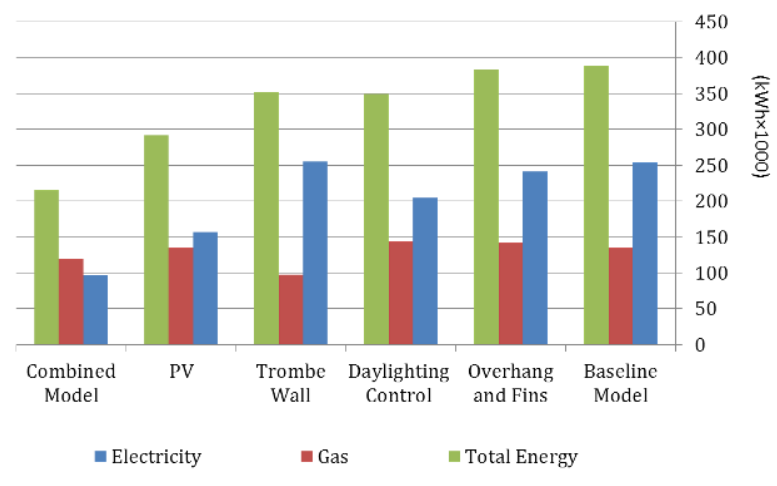

Figure 9. Office building energy consumption comparison

\section{CONCLUSIONS}

Office buildings among the public buildings are responsible for a great portion of energy consumption throughout the world. Energy efficiency improvement in this sector, by applying proper measures, has the potential for a tremendous overall reduction in energy consumption. In this study, solar system based retrofitting measures such as Daylighting Control System, Trombe wall and Photovoltaic were adopted to an office building located in Dayton, Ohio and the results are calibrated using the eQuest software. After modeling each of the proposed measure, the percentages of energy saving were calculated as follows;

-Adoption of the overhangs and fins for the west and east sides and overhangs for the south side may lead to 1.3 percent of energy conservation.

-Adoption of the daylighting control systems may lead to 10.3 percent of energy conservation.
-Adoption of the Trombe wall, as a passive heating system, on 50 percent of the south façade may lead to 9.3 percent of energy conservation.

-Adoption of PV array on 58 percent of the roof area together with all aforementioned retrofitting measures could lead to 45 percent energy saving in the office building.

In terms of economic perspectives, overhang and fins provide the best simply payback time around 1 year. Other solar system based retrofitting measures such as TW, DCS, and PV can provide simple payback with $1.5,2.5$, and 12 years respectively. PV turned out to be the most costly options although it provides the largest energy savings.

Although the implementation of the proposed combined measures can provide the greatest energy savings opportunity compared to other standalone application, decision maker or project managers for implementing these energy efficiency measures should consider trade-off decisions associated with economic benefits, energy savings, and environmental emissions reductions associate with each retrofit options.

\section{NOMENCLATURE}

$\begin{array}{ll}a & \text { Aspect ratio, H/L } \\ h_{\text {Cnet }} & \text { Net interior convection coefficient }\left(\mathrm{W} / \mathrm{m}^{2} . \mathrm{K}\right) \\ H & \text { Height }(\mathrm{m}) \\ K & \text { Thermal conductivity }(\mathrm{W} / \mathrm{m} . \mathrm{K}) \\ L & \text { Length of air gap spacing or thickness of wall }(\mathrm{m}) \\ N u & \text { Nusselt number } \\ q^{* x} & \text { Heat flux }\left(\mathrm{W} / \mathrm{m}^{2}\right) \\ R a & \text { Rayleigh number } \\ T_{1} & \text { Hot wall temperature }(\mathrm{K}) \\ T_{2} & \text { Cold wall temperature }(\mathrm{K})\end{array}$

\section{REFERENCES}

Albanese, M.V., Robinson, B.S., Brehob, E.G., Keith, S.M., 2012. Simulated and experimental performance of a heat pipe assisted solar wall. Solar Energy, 86, pp. 1552-62, https://doi.org/10.1016/j.solener.2012.02.017.

Ataie, A., Dehghani, M.J., 2017. Comparison of refrigerated warehouse energy demand with R-717 and R-507 using eQUEST mode. International Journal of Green Energy, 14(11), pp. 899-907, https://doi.org/10.1080/15435075.2017.1337016.

Ataie, A., Dehghani, M.J., 2016. Toward residential building energy conservation through the Trombe wall and ammonia ground source heat pump retrofit options, applying eQuest model. Advances in Energy Research, 4(2), pp. 107-120, DOI: 10.12989/eri.2016.4.2.107.

Bojic, M., Johannes, K., Kuznik, F., 2014. Optimizing energy and environmental performance of passive Trombe wall. Energy Build, pp. 70, 279-286, https://doi.org/10.1016/j.enbuild.2013.11.062.

Balcomb, J.D., 1992. Passive solar buildings, M IT Press, ISBN: 9780262023412. 
DOE, US Department of Energy 2018. EnergyPlus 8.8.0, https://energy.gov/eere/buildings/downloads/energyplus-0 (view at 06 Jan. 2018).

EIA, U.S. Energy Information Administration, 2012. Commercial Building Energy Consumption Survey (CBECS) https://www.eia.gov/consumption/commercial/data/2012/index. php?view=methodology (view at 06 Jan. 2018).

EIA, U.S. Energy Information Administration, 2018. Independent Statistics and Analysis, How Much Energy Is Consumed in Residential and Commercial Buildings in U.S? https://www.eia.gov/tools/faqs/faq.php?id=86\&t=1 (view at 06 Jan. 2018).

Ellis, P.G., 2003. Development and validation of the unvented trombe wall model in Energyplus, in Mechanical Engineering. University of Illinois at Urbana-Champaign.

EVO, Efficiency Valuation Organization, 2010. International Performance Measurementand Verification Protocol, Concepts and Options for Determining Energy and Water Saving, 1.

Gould, S., Hawkins, M., 2015. Modeling multifamily buildings with eQuest:a case study of prediction versus reality, ASHRAE.

Hedrick, R., Porter, F., 2011. Energy savings in high-rise buildings using high-reflective coatings.

Hirsch, J.J., 2018. DOE-2 based Building Energy Use and Cost Analysis Software: eQuest 3.65. http://www.doe2.com/equest (view at 06 Jan. 2018)

Irshad, K., Habiba, K., Thirumal, N., 2014. Energy and cost analysis of photo voltaic Trombe wall system in tropical climate. Energy Procedia, 50, pp. 71-78, https://doi.org/10.1016/j.egypro.2014.06.009.

Irshad, K., Habib, K., Thirumalaiswamy, N., Elmahdi, A.E.A., 2014. Performance analysis of photo voltaic Trombe wall for tropical climate. Applied Mechanics and Materials, pp. 465466, https://doi.org/10.1016/j.procir.2014.07.116.

Jaber, S., Ajib, S., 2011. Optimum design of Trombe wall system in Mediterranean region. Solar Energy, 85, pp. 18911898, https://doi.org/10.1016/j.solener.2011.04.025.

Jie, J., Wei, H., Gang, P., 2007. PV-Trombe wall design for buildings in composite climates. Solar Energy Eng, ASME, 129, pp. 431-437, DOI:10.1115/1.2770751.

Ke, M.T., Yeh, C.H., Jian, J.T., 2013. Analysis of building energy consumption parameters and energy savings measurement and verification by applying eQUEST software. Energy and Buildings, 61(0), pp. 100-107, https://doi.org/10.1016/j.enbuild.2013.02.012.

Kim, H., Stumpf, A., Kim, W., 2011. Analysis of an energy efficient building design through data mining approach. Automation in Construction, 20(1), pp. 37-43, https://doi.org/10.1016/j.autcon.2010.07.006.

Koyunbaba, B., Yilmaz, Z., Ulgen, K., 2013. An approach for energy modeling of a building integrated photovoltaic (BIPV) Trombe wall system. Energy Build, 67, pp. 680-688, https://doi.org/10.1016/j.enbuild.2011.06.031.
Koyunbaba, B., Yilmaz, Z., 2012. The comparison of Trombe wall systems with single glass, double glass and PV panels. Renew. Energy, 45, pp. 111-118, https://doi.org/10.1016/j.renene.2012.02.026.

Liu, Y.W., Feng, W., 2012. Integrating passive cooling and solar techniques into the existing building in south China. Advanced Materials Research, 368, pp. 3717-3720, DOI: 10.4028/www.scientific.net/AMR.368-373.3717.

Martinez, A., Noble, D., SCHILER, M., Paterson, M., 2012. Facade retrofit, strategies for energy reduction in an office building in a mild climate. 28th Conference on Opportunities, Limits \& Needs towards an Environmentally Responsible Architecture, Lima, Perú, November.

Sami, V., Gassman, J., 2006. A simultaneous modelling methodology to analyze passive solar performance of Trombe walls. 23rd Conference on Passive and Low Energy Architecture, Geneva, Switzerland.

Sozer, H., 2010. Improving energy efficiency through the design of the building envelope. Building and Environment, 45(12), pp. 25812593, https://doi.org/10.1016/j.buildenv.2010.05.004.

Stazi, F., Mastrucci, A., di Perna C., 2011. The behavior of solar walls in residential buildings with different insulation levels: an experimental and numerical study. Energy and Buildings, 47, pp. 217-229, https://doi.org/10.1016/j.enbuild.2011.11.039.

Sun, W., Ji, J., Luo, C., He, W., 2011. Performance of PVTrombe wall in winter correlated with south façade design. Appl. Energy, 88(1), pp. 224-231, https://doi.org/10.1016/j.apenergy.2010.06.002.

Trane. Trane Air Conditioning Economics (TRACE) 700, 2018. http://www.trane.com/ trace (view at 06 Jan. 2018).

Wan, K.K.W., Li, D.H.W., Liu, D., Lam, J.C., 2011. Future trends of building heating and cooling loads and energy consumption in different climates. Building and Environment, 46(1), pp. 223-234, https://doi.org/10.1016/j.buildenv.2010.07.016.

Wright, J.L., 1996. A correlation to quantify convective heat transfer between vertical window glazings. ASHRAE Transactions.

Yu, J., Yang, C., Tian, L., 2008. Low-energy envelope design of residential building in hot summer and cold winter zone in China. Energy and Buildings, 40(8), pp. 1536-1546, https://doi.org/10.1016/j.enbuild.2008.02.020.

Zhu, Y., 2006. Applying computer-based simulation to energy auditing: A case study. Energy and Buildings, 38(5), pp. 421-428, https://doi.org/10.1016/j.enbuild.2005.07.007. 